DOI: 10.19195/0137-1134.118.2

\author{
DARIUSZ MAKOWSKI \\ ORCID: 0000-0002-6096-8633 \\ Uniwersytet Łódzki
}

\title{
ROZWÓJ REGULACJI DOTYCZĄCYCH USTROJU I KOMPETENCJI INSPEKCJI PRACY W POLSCE
}

\begin{abstract}
Abstrakt: W 2019 roku mija 100 lat od utworzenia inspekcji pracy w Polsce. Z historycznego punktu widzenia możliwe jest wyodrębnienie trzech głównych okresów rozwoju regulacji dotyczących ustroju i kompetencji tej inspekcji, a mianowicie: okres dwudziestolecia międzywojennego, okres PRL oraz okres III RP. Biorąc pod uwagę zasięg oddziaływania uwarunkowań społecznych, gospodarczych i politycznych na polskie uregulowania dotyczące inspekcji pracy, można je podzielić na dwie grupy. Pierwsza obejmuje uwarunkowania o charakterze uniwersalnym (ogólnoświatowym), odzwierciedlające pewne ogólne tendencje i procesy, druga zaś ma zasięg lokalny. Te uwarunkowania z kolei są zasadniczo charakterystyczne tylko dla inspekcji pracy w naszym kraju.
\end{abstract}

Słowa kluczowe: inspekcja, nadzór, praca, ustrój, zadania

\section{UWAGI WSTĘPNE}

Od utworzenia inspekcji pracy w Polsce w 2019 roku mija 100 lat. Tak znamienita rocznica skłania do refleksji na temat rozwoju regulacji dotyczących ustroju i kompetencji tej podstawowej instytucji nadzoru państwa nad przestrzeganiem przepisów prawa pracy. Nie sposób nie podkreślić już na wstępie szczególnego kontekstu historycznego towarzyszącego wprowadzeniu pierwszych uregulowań związanych z inspekcją pracy w Polsce. Powołanie do życia tej inspekcji przypadło bowiem na okres rekonstrukcji państwa polskiego po przeszło 100 latach pozostawania pod zaborami. Okoliczność ta wyróżnia naszą inspekcję spośród inspekcji większości państw, a co więcej, nie pozostała bez wpływu na rozwiązania prawne przyjęte w początkowym okresie jej funkcjonowania.

Rozwój regulacji dotyczących inspekcji pracy pozostawał w oczywistym związku z dziejami państwa polskiego. Uwarunkowania natury ideologicznej, politycznej czy też społeczno-gospodarczej, charakterystyczne dla poszczególnych okresów polskiej państwowości, wpłynęły zasadniczo na treść norm regulujących ustrój i kompetencje inspekcji pracy. Wśród nich były takie, które wprowadzały 
zmiany o modelowym znaczeniu dla działalności inspekcji pracy, wyznaczając główne kierunki rozwoju regulacji w tej dziedzinie.

Mając na względzie powyższe uwagi, zasadne wydaje się wyodrębnienie trzech historycznych etapów rozwoju regulacji dotyczących inspekcji pracy w Polsce okresu dwudziestolecia międzywojennego, okresu PRL oraz okresu III RP. Będą one przedmiotem analizy w kolejnych punktach opracowania.

\section{OKRES DWUDZIESTOLECIA MIĘDZYWOJENNEGO}

Pierwsze regulacje poświęcone inspekcji pracy zostały ustanowione w szczególnym momencie dziejowym, przypadły bowiem na lata rekonstrukcji państwa polskiego po ponad stu latach utraty suwerenności. W tym kontekście bardzo wymowne jest to, że przepisy dotyczące inspekcji pracy przyjęto jako jedne z pierwszych. Niewątpliwie świadczy to o dużym znaczeniu, jakie od początku przypisywano jej w odrodzonym państwie polskim. Powołanie władz państwowych w postaci inspekcji pracy uznano za najbardziej elementarną podstawę organizacji bezpieczeństwa pracy ${ }^{1}$, a zarazem za ważny czynnik konsolidacji świeżo odzyskanej państwowości.

Pierwszym aktem prawnym dwudziestolecia międzywojennego regulującym działalność inspekcji pracy był tymczasowy dekret Naczelnika Państwa z 3 stycznia 1919 roku o urządzeniu i działalności inspekcji pracy $^{2}$. Jego wydanie poprzedzone było pracami nad projektami dotyczącymi inspekcji pracy, zapoczątkowanymi już w 1915 roku. Pracom koncepcyjnym nad kształtem pierwszych uregulowań towarzyszyło równoczesne tworzenie struktur polskiej inspekcji pracy. Dekret z 1919 roku w istocie utrwalał wcześniejszy stan faktyczny, stając się normatywną podstawą funkcjonowania istniejących już w dniu jego wejścia w życie organów inspekcyjnych ${ }^{3}$.

Analizując przepisy dekretu z 1919 roku oraz późniejsze akty dwudziestolecia, można stwierdzić, że na ówczesne rozwiązania prawne dotyczące inspekcji pracy wpłynęły głównie trzy czynniki: wcześniejsze pozostawanie przez Polskę pod zaborami, związane $\mathrm{z}$ tym tendencje zmierzające do konsolidacji państwa polskiego po odzyskaniu niepodległości, a także nabierający coraz większego znaczenia ruch robotniczy.

Pozostawanie przez nasz kraj pod zaborami sprawiło w szczególności, że dekret z 1919 roku o urządzeniu i działalności inspekcji pracy przygotowany został

1 Por. A. Mazurkiewicz, Zagadnienie organizacji bezpieczeństwa pracy, Warszawa 1938, s. 216.

2 Dziennik Praw Państwa Polskiego nr 5, poz. 90.

3 Szerzej por. M. Święcicki, Instytucje polskiego prawa pracy w latach 1918-1939, Warszawa 1960, s. 33-34. 
w dużym stopniu na podstawie założeń prawnych rosyjskiej inspekcji fabrycznej ${ }^{4}$. Dekret w wielu miejscach odwoływał się wprost do przepisów rosyjskich, w tym przede wszystkim do ustawy z 1886 roku o pracy w przemyśle ${ }^{5}$. Na podkreślenie zasługuje zwłaszcza wpływ tych przepisów na unormowanie zakresu zadań polskiej inspekcji pracy. Dekret z 1919 roku o inspekcji pracy powielił rosyjski model bardzo szerokiego zakresu tych zadań. Inspekcja pracy została obciążona między innymi zadaniami rozjemczymi i polubownymi, co było później dość powszechnie krytykowane ${ }^{6}$.

Innym czynnikiem wpływającym na kształt przepisów przyjętych w okresie dwudziestolecia międzywojennego w dziedzinie inspekcji pracy było dążenie, przejawiające się także w sferze legislacyjnej, do konsolidacji i umocnienia odrodzonego państwa polskiego. Szczególnie duże znaczenie miały przyjęte zasady powszechności oraz niezależności inspekcji. Warto podkreślić, że w tym zakresie zastosowane zostały rozwiązania inne niż znane z ustaw państw zaborczych. Przyjęcie zasady powszechności i niezależności polskiej inspekcji pracy świadczyło tym samym o daleko idącej samodzielności koncepcyjnej polskiego prawodawcy u progu odzyskanej państwowości.

Zasadę powszechności inspekcji pracy wyrażał art. 1 dekretu z 1919 roku, który stanowił, że inspekcja ta nadzoruje należyte stosowanie przepisów we wszystkich dziedzinach pracy najemnej. Dekret nie przewidywał ograniczeń odnośnie do zakresu działania inspekcji pracy, na przykład ze względu na wielkość zakładu pracy czy gałąź pracy, co było odejściem od modelu obowiązującego wcześniej na ziemiach byłego zaboru rosyjskiego, w którego miejsce wprowadzono zasadę stosowaną w krajach Europy Zachodniej. Gdy chodzi natomiast o zasadę niezależności inspekcji pracy, to dekret z 1919 roku zrywał ze stosowaną w byłych państwach zaborczych koncepcją inspekcyjnej zależności od organów administracji ogólnej, co uznawano ówcześnie za przejaw nowoczesnego podejścia ${ }^{7}$. Wprawdzie dekret nie formułował tej zasady wprost, ale z przepisów aktu z powodzeniem można było wywieść tę zasadę. O jej obowiązywaniu świadczył przede wszystkim art. 2 dekretu, który stanowił, że inspekcja pracy pozostaje pod zarządem Ministerstwa Pracy i Opieki Społecznej. Z użytego w tym przepisie sformułowania ,pod zarządem” wynikało, że inspekcja miała pewien zakres samodzielności nawet w obrębie tego Ministerstwa ${ }^{8}$. O niezależności inspekcji świadczył również art. 4 dekretu,

4 Por. M. Klott, Inspekcja pracy w Polsce, Warszawa 1937, s. 11; J. Piszczek, Administracyjno-prawne zagadnienia zwiazkowej inspekcji pracy, Toruń 1971, s. 11; E. Kołodziejczyk, Inspekcja pracy w Polsce 1919-1999, Warszawa 2003, s. 34-35.

5 Tekst tej ustawy znajduje się w opracowaniu pod red. S. Szymorowskiego, Ustawa o pracy w przemyśle, Warszawa 1922, s. 1-86.

6 Por. art. 11 pkt 5 dekretu. Por. też E. Lipiński, Inspekcja pracy, Warszawa 1916, s. 27-29, 43-44; M. Klott, op. cit., s. 21-22; A. Mazurkiewicz, op. cit., s. 217.

${ }^{7}$ Por. W. Landau, Drogi rozwoju polskiego ustawodawstwa pracy, [w:] Na froncie gospodarczym. W dziesiąta rocznicę odzyskania niepodległości, Warszawa 1928, s. 386.

8 Por. Tak M. Święcicki, op. cit., s. 35; podobnie E. Kołodziejczyk, op. cit., s. 35. 
według którego zwierzchni nadzór nad czynnościami inspektorów pracy oraz kierownictwo nad tymi czynnościami należały do Głównego Inspektora Pracy, a nie do Ministerstwa. Stosownie zaś do art. 5 Główny Inspektor Pracy i inni inspektorzy pracy byli mianowani przez „Najwyższą władzę"

Jeszcze innym czynnikiem wpływającym na model polskiej inspekcji pracy w pierwszym okresie jej działalności był przybierający na sile w Europie i na świecie ruch robotniczy, występujący z hasłami poprawy bytu socjalnego robotników, oraz związane z tym coraz powszechniejsze nastroje rewolucyjne znacznej części pracujących. Przepisy o inspekcji pracy miały w związku z tym do odegrania ważną rolę. Będąc częścią ochronnego ustawodawstwa fabrycznego, miały przyczyniać się do łagodzenia najbardziej radykalnych nastrojów społecznych. Uwarunkowania te niewątpliwie wpłynęły na kompetencje inspekcji jako organu rozwiązywania sporów. Przepisy okresu dwudziestolecia międzywojennego w dziedzinie inspekcji pracy wyrażały jednocześnie zasadę ochrony pracownika ${ }^{10}$. Bardzo wyraźnie formułował ją art. 1 dekretu z 1919 roku, określający inspekcję jako organ nadzoru nad należytym stosowaniem przepisów o ochronie pracy o jednoznacznie sprecyzowanym celu działania — zapewnieniu pracownikom korzyści przyznanych im przez obowiązujące prawodawstwo.

Drugim najważniejszym aktem dwudziestolecia międzywojennego dotyczącym inspekcji pracy było rozporządzenie (z mocą ustawy) Prezydenta Rzeczypospolitej z 14 lipca 1927 roku o inspekcji pracy ${ }^{11}$, które uchyliło dekret z 1919 roku. Rozporządzenie to przejęło podstawowe rozwiązania prawne ustanowione przez dekret z 1919 roku. Potwierdziło w szczególności obowiązywanie zasady niezależności inspekcji pracy. Rozporządzenie stanowiło, że inspekcja jest organem administracji państwowej podległym Ministrowi Pracy i Opieki Społecznej, który jest naczelną władzą w zakresie działania inspekcji pracy, sprawując zwierzchni nadzór nad działalnością inspekcji ${ }^{12}$. W strukturze administracji publicznej inspekcja pracy należała do tak zwanej administracji specjalnej (niezespolonej), wyodrębnionej i niezależnej od administracji ogólnej ${ }^{13}$.

W porównaniu do dekretu z 1919 roku w rozporządzeniu z 1927 roku zmienił się model regulacji środków działania nadzorczego inspekcji pracy. Na gruncie dekretu z 1919 roku inspekcja pozbawiona była zasadniczo uprawnienia do stosowania środków władczych, co znacznie osłabiało możliwości skutecznego egzekwowania przepisów. Rozporządzenie z 1927 roku wyposażyło w związku z tym

9 W celu podkreślenia niezależności inspekcji, a także rangi urzędu inspektorskiego pierwsze wnioski nominacyjne w inspekcji były przedstawiane bezpośrednio Naczelnikowi Państwa Józefowi Piłsudskiemu; por. H. Krahelska, M. Kirstowa, S. Wolski, Ze wspomnień inspektora pracy, t. 1, Warszawa 1936, s. 39-40.

10 Tak M. Święcicki, op. cit., s. 35.

11 Dz.U. Nr 67, poz. 590 ze zm.

12 Por. art. 1 i 13 rozporządzenia.

13 Por. M. Gersdorf, J. Jagielski, K. Rączka, Komentarz do ustawy o Państwowej Inspekcji Pracy, Warszawa 2008, s. 13. 
inspektorów pracy w prawo wydawania wiążących nakazów ${ }^{14}$, co stanowiło równocześnie przejaw własnej koncepcji inspekcji pracy nieznanej żadnej z inspekcji państw zaborczych ${ }^{15}$.

Rangę przepisów dotyczących inspekcji pracy zawartych w dekrecie z 1919 roku oraz w rozporządzeniu z 1927 roku wzmacniały dodatkowo regulacje konstytucyjne. Były one związane z ochroną pracy i rolą państwa w jej sprawowaniu. Wprawdzie nie stanowiły wprost o inspekcji pracy, ale nie ulegało wątpliwości, że realizacja określonych w nich obowiązków państwa w zakresie ochrony pracy wyrażała się przede wszystkim w działalności tej inspekcji ${ }^{16}$. Konstytucja marcowa z dnia 17 marca 1921 roku $^{17}$ już we wstępie zapowiadała, że jednym z celów ustawy konstytucyjnej będzie poszanowanie pracy, danie jej należnych praw i otoczenie jej specjalną opieką państwa. Zapowiedź ta została następnie rozwinięta w art. 102 Konstytucji, umieszczonym w rozdziale o powszechnych obowiązkach i prawach obywatelskich, który stanowił, że ,praca, jako główna podstawa bogactwa Rzeczypospolitej, pozostawać ma pod szczególną ochroną Państwa”, a następnie, że ,każdy obywatel ma prawo do opieki Państwa nad jego pracą”. Zadanie państwa polegające na sprawowaniu nadzoru nad pracą jeszcze bardziej stanowczo formułowała Konstytucja kwietniowa - ustawa konstytucyjna z dnia 23 kwietnia 1935 roku $^{18}$. Ustawa ta w art. 8 ust. 2, umiejscowionym w części I zatytułowanej Rzeczpospolita Polska, a więc dotyczącej ustroju państwa, deklarowała nie tylko, że państwo roztacza opiekę nad pracą, lecz także że sprawuje nadzór nad jej warunkami.

Reasumując, należy stwierdzić, że mimo obiektywnych trudności związanych z odbudową struktur państwa po okresie zaborów bardzo szybko stworzono normatywne podstawy dla działalności polskiej inspekcji pracy. Miały one źródło nie tylko w ustawodawstwie zwykłym, lecz także konstytucyjnym, a organizacja inspekcji została oparta na nowoczesnych i dobrze przemyślanych zasadach.

\section{OKRES PRL}

\subsection{INSPEKCJA PRACY W LATACH 1945-1954}

Po zakończeniu drugiej wojny światowej początkowo nie wprowadzano zmian przepisów dotyczących inspekcji pracy. Zachowano rozwiązania prawne, jakie zo-

14 Por. art. 23 rozporządzenia.

15 Tak J. Piszczek, op. cit., s. 13-14, 69-70. W tej sprawie por. też A. Raczyński, Polskie prawo pracy, Warszawa 1930, s. 280.

16 Por. T. Kozłowski, Proces scalania Inspekcji Pracy w Polsce w latach 1919-1928, „Prawo" 2006, nr 298, s. 198.

17 Ustawa z 17 marca 1921 roku - Konstytucja Rzeczypospolitej Polskiej, Dz.U. Nr 44, poz. 267.

18 Dz.U. Nr 30, poz. 227. 
stały ustanowione w okresie dwudziestolecia międzywojennego, wciąż też obowiązywało rozporządzenie z 1927 roku o inspekcji pracy. Oznaczało to formalną kontynuację przedwojennego modelu inspekcji pracy.

W kolejnych latach coraz wyraźniej można było jednak zauważyć zmieniające się podejście państwa do pozycji i roli inspekcji pracy. Wynikało to z założeń ideologicznych i ustrojowo-politycznych, właściwych dla państw socjalistycznych tej epoki. Priory tetem stało się zwiększenie udziału „mas pracujących w rządzeniu państwem"19, co wyrażało się w szczególności eksponowaniem znaczenia związków zawodowych. Jednocześnie dużą nieufność władz wzbudzały w nowym ustroju instytucje cieszące się niezależnością i samodzielnością, a do takich zaliczała się inspekcja pracy według modelu przedwojennego.

Wskazane uwarunkowania natury ideologicznej legły u podstaw pierwszych zmian legislacyjnych dotyczących inspekcji pracy. Zostały one wprowadzone przepisami dwóch aktów prawnych przyjętych w 1950 roku. Pierwszym z nich była ustawa z dnia 4 lutego 1950 roku o społecznej inspekcji pracy ${ }^{20}$. Formalnie rozpoczęła ona proces „uspołeczniania” inspekcji pracy, polegający na przekazywaniu funkcji inspekcji pracy samym pracownikom i ich przedstawicielom ${ }^{21}$. Dążenie do powierzenia w większym zakresie funkcji inspekcyjnych związkom zawodowym znalazło wyraz właśnie w ustawie z dnia 4 lutego 1950 roku o społecznej inspekcji pracy, działającej jako organ związków zawodowych ${ }^{22}$.

Drugim aktem prawnym przyjętym $\mathrm{w}$ tym okresie w odniesieniu do inspekcji pracy była ustawa z dnia 20 marca 1950 roku o terenowych organach jednolitej władzy państwowej ${ }^{23}$. Na jej podstawie organy inspekcji pracy w terenie zostały włączone do systemu rad narodowych i podporządkowane właściwym prezydiom tych $\operatorname{rad}^{24}$, przy równoczesnym zachowaniu na szczeblu centralnym dotychczasowej podległości inspekcji ministrowi właściwemu do spraw pracy. W ten sposób zniesiono odrębność organizacyjną terenowych organów inspekcji pracy, ponieważ była ona nie do pogodzenia z charakterystyczną dla państw socjalistycznych koncepcją podporządkowania całej administracji terenowej organom przedstawicielskim oraz naczelną zasadą tworzenia jednolitych organów terenowej władzy państwowej ${ }^{25}$. W ustawie z dnia 20 marca 1950 roku normatywny wyraz znalazło tym samym

19 Por. K. Rusinek, Z dziejów walk o ochronę pracy, Warszawa 1957, s. 368.

20 Dz.U. z 1955 r. Nr 20, poz. 134.

21 Takiego określenia użyła między innymi M. Matey, por. eadem, Inspekcja pracy - model polski a tendencje światowe, Warszawa-Łódź 1988, s. 219. Zjawisko „uspołeczniania” inspekcji pracy autorka ta definiuje jako współdziałanie z inspekcją samych pracowników lub reprezentujących ich związków zawodowych.

22 Por. art. 1 ustawy o społecznej inspekcji pracy z 1950 roku.

23 Dz.U. Nr 14, poz. 130 ze zm.

24 Por. art. 36 i 37 ustawy z 20 marca 1950 roku.

25 Szerzej o organizacji inspekcji pracy w systemie rad narodowych por. K. Rusinek, op. cit., s. 369-370; J. Piszczek, op. cit., s. 21. 
zapatrywanie, że w nowych warunkach ustrojowych nieuzasadnione było wyodrębnienie i uniezależnienie inspekcji pracy od organów władzy państwoweje ${ }^{26}$.

Włączenie terenowych organów inspekcji pracy do systemu rad narodowych miało ten skutek, że przyjęto rozwiązanie organizacyjne, które było niezgodne z obowiązującymi już w tym czasie standardami Międzynarodowej Organizacji Pracy (MOP). Konwencja MOP nr 81 z 1947 roku o inspekcji pracy w przemyśle i handlu wymaga bowiem, aby inspekcja podlegała w całości władzy centralnej, nie zaś lokalnej27, a według zalecenia MOP nr 20 z 1923 roku dotyczącego inspekcji pracy powinna ona podlegać bezpośredniej i wyłącznej kontroli władzy państwowej. W myśl tego zalecenia inspekcja pracy nie powinna podlegać kontroli władz miejscowych lub być w jakikolwiek sposób uzależniona od nich w związku z wykonywaniem którejkolwiek ze swych czynności ${ }^{28}$. Zniesienie odrębności organizacyjnej terenowych organów inspekcji pracy ustawą z dnia 20 marca 1950 roku było w istocie równoznaczne z prawną i faktyczną utratą niezależności przez tę inspekcję.

\subsection{INSPEKCJA PRACY W LATACH 1954-1981}

Swoistym uwieńczeniem zapoczątkowanego ustawami z 1950 roku procesu uspołeczniania inspekcji pracy stał się uchwalony dnia 10 listopada 1954 roku dekret Rady Państwa o przejęciu przez związki zawodowe zadań w dziedzinie wykonywania ustaw o ochronie, bezpieczeństwie i higienie pracy oraz sprawowania inspekcji pracy $^{29}$. Na mocy tego aktu powołano do życia techniczną inspekcję pracy ${ }^{30}$. Był to akt o przełomowym znaczeniu z punktu widzenia modelu inspekcji pracy. $\mathrm{Na}$ jego podstawie dotychczasowe funkcje inspekcji pracy zostały bowiem przekazane związkom zawodowym. Zmiany ukierunkowane na ,uspołecznianie” inspekcji pracy doprowadziły ostatecznie do utraty przez nią charakteru organu państwowego. Stała się ona inspekcją związkową. Rozwiązanie to było wzorowane na radzieckiej ochronie pracy sprawowanej przez związki zawodowe, przyjętej wcześniej także przez inne państwa socjalistyczne ${ }^{31}$. W płaszczyźnie teoretycznoprawnej wywodzono je z koncepcji zlecania zadań państwowych organizacjom społecznym. Związki zawodowe miały pełnić zadania inspekcji pracy na zasadzie funkcji zleconych przez państwo, wobec czego uważano, że nie traciły charakteru funkcji państwowych ${ }^{32}$.

26 Por. J. Szczerski, Państwowa Inspekcja Pracy, „Praca i Zabezpieczenie Społeczne” 1981, nr 9, s. 17.

27 Por. art. 4 konwencji MOP nr 81; Dz.U. z 1997 r. Nr 72, poz. 450.

28 Por. pkt 10 zalecenia MOP nr 20.

29 Tekst jedn. Dz.U. z 1968 r. Nr 8, poz. 47 ze zm.

30 Por. art. 1 ust. 2 dekretu, na podstawie którego dotychczasową terenową inspekcję pracy przekształcono w techniczną inspekcję pracy.

31 Por. J. Piszczek, op. cit., s. 52-53; J. Wąsowski, Techniczna inspekcja pracy, Warszawa 1959, s. 7; M. Matey, op. cit., s. 222.

32 Por. J. Szczerski, op. cit., s. 18; T. Liszcz, Państwowa Inspekcja Pracy - strażnik praworządności w stosunkach pracy, „Kontrola Państwowa” 2006, nr 3, s. 50; J. Wąsowski, op. cit., s. 7. 
Włączenie w 1954 roku zadań inspekcji pracy do zakresu kompetencji związków zawodowych miało doniosłe skutki w sferze organizacji oraz zakresu działania inspekcji pracy. W sferze organizacyjnej zmiana ta doprowadziła do całościowego przejęcia zadań inspekcji pracy przez związki zawodowe, realizowanych przez dwie równolegle występujące inspekcje pracy — społeczną inspekcję pracy (działającą na podstawie ustawy z 1950 roku o społecznej inspekcji pracy) oraz techniczną inspekcję pracy (działającą na podstawie dekretu z 1954 roku). Inspekcja techniczna, w odróżnieniu od inspekcji społecznej, zachowała charakter inspekcji zawodowej. Innym skutkiem w sferze organizacyjnej usytuowania inspekcji pracy w strukturach związków zawodowych była zmiana polegająca na zastąpieniu dotychczas obowiązującej terytorialnej organizacji inspekcji organizacją branżową ${ }^{33}$. Każdy z 23 ówczesnych branżowych związków zawodowych dysponował niejako własną inspekcją pracy sprawującą kontrolę nad wszystkimi zakładami objętymi działalnością każdego z tych związków zawodowych ${ }^{34}$. W literaturze wyrażona została w związku z tym ocena, że „w konsekwencji przyjęcia zasady branżowej jako podstawy organizacyjnej związkowej inspekcji pracy przesądzone zostało, że mamy do czynienia nie z jedną, a z 23 odrębnymi inspekcjami pracy"35. Zastąpienie terytorialnej organizacji inspekcji pracy organizacją branżową było poniekąd wymuszone strukturą samych związków zawodowych, opartą na zasadzie podziału pionowego, to jest według gałęzi pracy ${ }^{36}$. Organizacja inspekcji pracy została w ten sposób dostosowana do branżowej struktury związków zawodowych, którym podlegała.

Skutki powierzenia zadań inspekcji pracy związkom zawodowym w płaszczyźnie zakresu działania inspekcji polegały z kolei na daleko idącym ograniczeniu tego zakresu. Do inspekcji technicznej należał jedynie nadzór nad urządzeniami technicznymi zakładów pracy oraz nad warunkami i organizacją pracy pod względem zabezpieczenia życia i zdrowia pracowników ${ }^{37}$. Zakres kompetencji inspekcji ograniczony został do dziedziny bhp oraz do zagadnień ściśle związanych z bhp.

Stan prawny ukształtowany dekretem z 1954 roku nie uległ większym zmianom aż do połowy lat sześćdziesiątych XX wieku, kiedy to na mocy ustawy z 30 marca 1965 roku o bezpieczeństwie i higienie pracy ponownie wyposażono inspekcję pracy w szeroki rzeczowo zakres uprawnień kontrolno-nadzorczych ${ }^{38}$. Ustawa z 1965 roku przyznała inspektorom pracy kompetencje do sprawowania nadzoru

33 Por. art. 1 ust. 2 dekretu z 1954 roku.

34 Por. E. Modliński, Inspekcja pracy. Odpowiedzialność karna w stosunkach pracy, Warszawa 1979, s. 20-21.

35 Por. J. Piszczek, op. cit., s. 54-55.

36 Por. W. Szubert, Zarys prawa pracy, Warszawa 1980, s. 283.

37 Por. w szczególności art. 5 ust. 3 dekretu.

38 Por. art. 49 ust. 1 pkt 2 ustawy o bezpieczeństwie i higienie pracy, Dz.U. Nr 13, poz. 91 ze zm. Szerzej o zmianach wprowadzonych tą ustawą por. J. Licki, Prawo pracy w zarysie. Część II - szczegółowa, Warszawa 1969, s. 463-468. 
nad przestrzeganiem przez zakłady pracy przepisów prawa pracy, a w szczególności przepisów o stosunku pracy, o bhp, o pracy młodocianych i kobiet, o czasie pracy i urlopach. Organizacyjnie inspekcja pracy pozostawała nadal w strukturach związków zawodowych.

Zasadniczych zmian w odniesieniu do inspekcji pracy nie wniosła kodyfikacja prawa pracy, dokonana ustawą z dnia 26 czerwca 1974 roku ${ }^{39}$, chociaż niewątpliwie wyznaczyła nowy, ważny etap rozwoju prawa pracy w Polsce. Inspekcji pracy poświęcony był art. 209 k.p., który w $§ 1$ stanowił, że inspekcja pracy sprawuje nadzór nad stanem bezpieczeństwa i higieny pracy oraz nad przestrzeganiem prawa pracy. W art. $209 \S 2$ k.p. zaś zawarto normę odsyłającą, zgodnie z którą zakres działania i organizację pracy miały określić odrębne przepisy. Odsyłając do odrębnych przepisów w przedmiocie zakresu działania i organizacji inspekcji pracy, kodeks utrzymał w mocy te rozwiązania modelowe, które przed 1 stycznia 1975 roku (dzień wejścia w życie kodeksu) obowiązywały na podstawie dekretu z 1954 roku oraz ustawy z 1965 roku. W chwili wejścia w życie kodeksu inspekcja pracy pozostała więc organem podporządkowanym związkom zawodowym, działającym na podstawie branżowej struktury organizacyjnej. Przepis art. 209 k.p. uważany był w związku z tym za normę mającą znaczenie jedynie porządkujące ${ }^{40}$. Warto jednak podkreślić, że art. 209 włączony został do działu X kodeksu poświęconego bhp, co może świadczyć o tym, że mimo poszerzenia na podstawie ustawy z 1965 roku zakresu działania inspekcji pracy na dziedziny wykraczające poza bhp, to właśnie z tą sferą wciąż najściślej łączono zadania tej inspekcji. Poza art. 209 k.p. inspekcji pracy były poświęcone także przepisy art. 281-290 k.p., w których uregulowano kompetencje karno-administracyjne inspektorów pracy w postępowaniu w sprawach o wykroczenia przeciwko prawom pracownika.

\subsection{INSPEKCJA PRACY W LATACH 1981-1989}

Nowy etap w dziejach polskiej inspekcji pracy otworzyła ustawa z dnia 6 marca 1981 roku o Państwowej Inspekcji Pracy ${ }^{41}$. Jej przyjęcie związane było z załamaniem się dotychczasowego modelu związków zawodowych, w których strukturach działała ówczesna związkowa inspekcja pracy. Na fali strajków i protestów społecznych, jakie przetoczyły się przez Polskę w 1980 roku, doszło do podpisania tak zwanych porozumień sierpniowych, w wyniku których zrealizowano między innymi postulat pluralizmu związkowego. Skutkowało to powstaniem w kolejnych miesiącach, oprócz 23 już działających branżowych związków zawodowych, ponad 60 nowych, w tym NSZZ ,Solidarność”, przy równoczesnym rozwiązywaniu

39 Ustawa z dnia 26 czerwca 1974 roku — Kodeks pracy, tekst jedn. Dz.U. z 2019 r. poz. 1040 ze zm.

40 Tak np. A. Kijowski, Odpowiedzialność za wykroczenia przeciwko przepisom ustawodawstwa pracy, [w:] Studia nad kodeksem pracy, red. W. Jaśkiewicz, Poznań 1975, s. 270.

41 Tekst jedn. Dz.U. z 2001 r. Nr 124, poz. 1362 ze zm. 
dotychczas działających związków. Utrzymanie modelu związkowej inspekcji pracy nie było już możliwe, co rodziło pilną potrzebę dostosowania stanu prawnego w dziedzinie inspekcji pracy do nowych warunków. Problemem była w szczególności prawna legitymizacja działania inspektorów pracy ${ }^{42}$.

W tych okolicznościach ustawą z dnia 6 marca 1981 roku przywrócono inspekcji pracy charakter organu państwowego, zrywając w ten sposób z powszechnie stosowanym w krajach socjalistycznych modelem inspekcji związkowej. Inspekcję podporządkowano naczelnemu organowi władzy państwowej, jakim w tym okresie była Rada Państwa ${ }^{43}$. Stosownie do art. 2 ustawy PIP podlegała Radzie Państwa, która sama podlegała Sejmowi ${ }^{44}$, nadzór zaś nad działalnością PIP powierzono Prezesowi NIK ${ }^{45}$. Ustawa przywróciła też zasadę terytorialnej organizacji inspekcji pracy.

W porównaniu do okresu wcześniejszego, to jest stanu prawnego ukształtowanego pod rządem dekretu z 1954 roku, w ustawie z 1981 roku przyjęto zatem wiele zmian o fundamentalnym znaczeniu. Jest godne podkreślenia, że większość z nich nawiązywała do tradycji polskiej inspekcji pracy okresu dwudziestolecia międzywojennego. Dotyczy to w szczególności powrotu do koncepcji państwowego charakteru inspekcji pracy, szerokiego zakresu właściwości przedmiotowej i podmiotowej inspekcji, a także terytorialnej zasady organizacyjnej inspekcji. W stanie prawnym ukształtowanym ustawą z 1981 roku PIP stała się szczególnym, wyspecjalizowanym organem państwowym szeroko rozumianego nadzoru nad przestrzeganiem prawa pracy.

\section{OKRES III RP}

\subsection{INSPEKCJA PRACY W LATACH 1989-2007}

Jeszcze w okresie obowiązywania ustawy o PIP z 1981 roku bardzo ważną zmianę dotyczącą pozycji PIP w systemie organów państwowych przyniósł rok 1989. Mianowicie na podstawie ustawy z dnia 29 maja 1989 roku o przekazaniu dotychczasowych kompetencji Rady Państwa Prezydentowi Polskiej Rzeczypospolitej Ludowej i innym organom państwowym PIP stała się organem podległym

42 Por. E. Kołodziejczyk, op. cit., s. 244-245. W tej sprawie por. też J. Knyziak, Związkowy nadzór nad warunkami pracy — w jakiej formie możliwy obecnie?, „Ochrona Pracy” 1981, nr 4, s. 5.

43 Według stanu prawnego obowiązującego w dniu wejścia w życie ustawy o PIP z 1981 roku Rada Państwa była naczelnym organem władzy państwowej, której kompetencje określały art. 30 33 Konstytucji PRL z 22 lipca 1952 roku, tekst jedn. Dz.U. z 1976 r. Nr 7, poz. 36 ze zm.

44 Por. art. 30 ust. 2 Konstytucji PRL z 1952 roku.

45 Na mocy art. 2 pkt 1 ustawy z 24 lipca 1985 roku o zmianie ustawy o związkach zawodowych i niektórych innych ustaw określających uprawnienia związków zawodowych (Dz.U. Nr 35, poz. 162) nadzór nad PIP, poza Prezesem NIK, powierzono także związkom zawodowym. 
bezpośrednio Sejmowi, a nadzór nad inspekcją przejęła Rada Ochrony Pracy ${ }^{46}$. W ten sposób formalnoprawny wyraz znalazło prezentowane ówcześnie zapatrywanie, że nadzór Prezesa NIK nad PIP był zbędny, gdyż PIP powinna, jak uważano, podlegać tylko Sejmowi. Podnoszono, że podstawą skutecznego nadzoru wykonywanego przez PIP jest zapewnienie jej swobody i niezależności, którym nie sprzyja wielość szczebli organizacyjnych ${ }^{47}$.

Pozycja PIP wzmocniła się w wyniku nowelizacji kodeksu pracy dokonanej ustawą z dnia 2 lutego 1996 roku $^{48}$. Ustawa ta włączyła do kodeksu art. $18^{4}$ (wciąż obowiązujący), który w $§ 1$ stanowi, że PIP sprawuje nadzór i kontrolę przestrzegania prawa pracy, w tym przepisów i zasad bhp, a w $\S 3$, że organizację i zakres działania PIP określają odrębne przepisy. Kodeks określa więc tylko ogólne normatywne ramy działalności PIP, którą w szerszym zakresie ma regulować osobna ustawa. Trzeba jednak podkreślić, że art. $18^{4}$ zamieszczony został w osobnym rozdziale kodeksu poświęconym nadzorowi i kontroli przestrzegania prawa pracy. Zmianę tę należy tym samym odczytywać jako wyraz nobilitacji i docenienia przez ustawodawcę znaczenia inspekcji pracy.

Zagadnienie państwowego nadzoru nad warunkami pracy znalazło również należne mu miejsce w przyjętej rok później Konstytucji RP z dnia 2 kwietnia $1997 \mathrm{roku}^{49}$. Za konstytucyjną podstawę działalności PIP, jak również innych organów państwowych uznaje się normę zawartą w art. 24 Konstytucji RP. Stanowi on w zdaniu pierwszym, że praca znajduje się pod ochroną Rzeczypospolitej Polskiej, a w zdaniu drugim, że państwo sprawuje nadzór nad warunkami wykonywania pracy. To właśnie zdanie drugie art. 24 Konstytucji RP potwierdza słuszność tezy o konstytucyjnym umocowaniu inspekcji pracy ${ }^{50}$. Państwowy nadzór nad warunkami wykonywania pracy jest rozwinięciem zasady ochrony państwa nad pracą, sformułowanej w zdaniu pierwszym art. 24 Konstytucji RP ${ }^{51}$. Szczególną wymowę ma to, że art. 24 umieszczony został w rozdziale I Konstytucji pt.

46 Por. art. 8 pkt 1 ustawy z 29 maja 1989 roku, Dz.U. Nr 34, poz. 178. Rada Ochrony Pracy była organem doradczym i opiniodawczym w sprawach objętych zakresem działania PIP; por. art. 6 ust. 1 ustawy o PIP z 1981 roku. W 1985 roku Rada została przekształcona z organu doradczego na organ programowania i kontroli działalności PIP; por. art. 2 pkt 2 cytowanej wcześniej ustawy z 24 lipca 1985 roku o zmianie ustawy o związkach zawodowych i niektórych innych ustaw określających uprawnienia związków zawodowych.

47 Por. J. Barański, Orzekanie przez inspektorów pracy w sprawach o wykroczenia przeciwko prawom pracownika, Warszawa 1984, s. 18-19.

48 Dz.U. Nr 24, poz. 110.

49 Dz.U. Nr 78, poz. 483 ze zm.

50 Por. P. Winczorek, Komentarz do Konstytucji Rzeczypospolitej Polskiej z dnia 2 kwietnia 1997 roku, Warszawa 2008, s. 64; B. Banaszak, Konstytucja Rzeczypospolitej Polskiej. Komentarz, Warszawa 2012, s. 181; A. Sobczyk, Prawo pracy w świetle Konstytucji RP, t. 1, Warszawa 2013, s. 47; W. Masewicz, Ł. Kasprowicz, Ochrona pracy jako problem prawno społeczny, „Studia z Zakresu Prawa Pracy i Polityki Społecznej" 2015, 1, s. 375.

51 Por. W. Skrzydło, Konstytucja Rzeczypospolitej Polskiej. Komentarz, Warszawa 2013, s. 36; A. Sobczyk, op. cit., s. 49. 
Rzeczpospolita, a więc dotyczącym ustroju państwa. Podnosi to ochronę pracy do najwyższej rangi i sprawia, że jest ona jedną z zasad ustrojowych tej Konstytucji ${ }^{52}$. Jest swego rodzaju nobilitacją ustanowionej w nim zasady ochrony pracy i związanego z nią nadzoru PIP nad warunkami wykonywania pracy. Pod tym względem polska Konstytucja wyróżnia się na tle konstytucji innych państw europejskich, w których zagadnienie to regulowane jest $\mathrm{z}$ reguły w rozdziałach poświęconych podstawowym prawom obywatelskim. Większość obcych ustaw zasadniczych nie eksponuje też tak wyraźnie jak polska Konstytucja obowiązku państwa sprawowania nadzoru nad pracą ${ }^{53}$.

\subsection{INSPEKCJA PRACY NA GRUNCIE USTAWY O PAŃSTWOWEJ INSPEKCJI PRACY Z 2007 ROKU}

Obecnie działalność inspekcji pracy reguluje ustawa z dnia 13 kwietnia 2007 roku o Państwowej Inspekcji Pracy ${ }^{54}$, która zastąpiła wcześniej obowiązującą ustawę z dnia 6 marca 1981 roku. Jak wynikało z uzasadnienia do projektu ustawy z 2007 roku, została ona wprowadzona w celu usprawnienia działań PIP w związku z głębokimi przemianami społeczno-gospodarczymi, jakie zaszły w Polsce w ostatnich latach. Ustawa miała na celu dostosowanie form i zakresu realizacji zadań PIP do nowych potrzeb, spowodowanych rozwojem i zróżnicowaniem form prawno-organizacyjnych podmiotów zatrudniających pracowników, wzrostem konkurencyjności firm i pogłębiającą się niestabilnością rynku pracy. Celem ustawy były: poprawa skuteczności działań na rzecz ochrony praw pracownika w sferze prawa pracy, zapobieganie zjawisku nielegalnego zatrudnienia, usprawnienie procedur kontroli i wykonywania nadzoru przez organy PIP, jak również zaostrzenie sankcji wobec pracodawców za wykroczenia i przestępstwa przeciwko prawom osób wykonujących pracę zarobkową ${ }^{55}$.

Stosownie do art. 1 ustawy z 2007 roku PIP jest organem powołanym do sprawowania nadzoru i kontroli przestrzegania prawa pracy, w szczególności przepisów i zasad bhp, a także przepisów dotyczących legalności zatrudnienia i innej pracy zarobkowej w zakresie określonym w ustawie. Zakres zadań kontrolno-nadzorczych PIP jest zatem szeroki i obejmuje całe prawo pracy. Kontroli PIP podlegają wszyscy

52 Por. W. Skrzydło, op. cit., s. 36; A. Sobczyk, D. Buch, [w:] Konstytucja RP, t. 1, red. M. Safjan, L. Bosek, Warszawa 2016, s. 645-646. Według A. Sobczyka z faktu wyeksponowania ochrony pracy w systemie zasad ustrojowych Konstytucji nie należy jednak wyciągać wniosku odnośnie do uprzywilejowania pracy w stosunku do innych wartości ustrojowych, por. idem, op. cit., s. 54.

53 Szerzej por. D. Makowski, Inspekcja pracy jako instytucja państwowego nadzoru nad przestrzeganiem prawa pracy, Łódź 2017, s. 47-50.

54 Tekst jedn. Dz.U. z 2019 r. poz. 1251.

$55 \mathrm{Z}$ uzasadnienia do projektu ustawy, druk sejmowy nr 712, http://orka.sejm.gov.pl/Druki5ka.nsf/0/EA9524A024BBA366C1257196003E15D8/\$file/712.pdf. Por. też J. Zalewski, Państwowa Inspekcja Pracy - organizacja, zakres działania i uprawnienia, „Inspektor Pracy”, dodatek tematyczny 2007 , nr 2, s. 2. 
pracodawcy, a nadto inne podmioty wymienione w art. 13 ustawy ${ }^{56}$. Ustawa zachowała również dotychczasową pozycję prawno-ustrojową PIP, stanowiąc w art. 2, że PIP podlega Sejmowi, nadzór zaś nad PIP w zakresie określonym w ustawie sprawuje Rada Ochrony Pracy. W porównaniu do wcześniej obowiązującej ustawy z 1981 roku nie zmieniła się też struktura organizacyjna PIP, której organami są Główny Inspektor Pracy, okręgowi inspektorzy pracy oraz inspektorzy pracy, działający w ramach właściwości terytorialnej okręgowych inspektoratów pracy ${ }^{57}$.

Ustawa z 2007 roku nie wprowadziła zatem zmian o charakterze (znaczeniu) modelowym ${ }^{58}$. Stosunkowo największe znaczenie miało wyposażenie inspekcji pracy w kompetencję do wykonywania kontroli legalności zatrudnienia i innej pracy zarobkowej oraz kontroli wykonywania pracy przez cudzoziemców ${ }^{59}$. Nie kwestionując znaczenia tego problemu, należy podkreślić, że zmiana ta świadczyła tylko o poszerzeniu zakresu zadań kontrolnych inspekcji, nie wnosząc żadnej modyfikacji obowiązującej już wcześniej zasady pełnego zakresu przedmiotowego uprawnień kontrolnych inspekcji 60 .

\section{UWAGI KOŃCOWE}

Podjęte w niniejszym opracowaniu rozważania na temat rozwoju regulacji dotyczących ustroju i kompetencji inspekcji pracy w Polsce prowadzą do wniosku, że na rozwój ten kluczowy wpływ miały uwarunkowania dwojakiego rodzaju. Po pierwsze, były to uwarunkowania o charakterze uniwersalnym, to jest o zasięgu ogólnoświatowym. Oddziaływanie tego typu czynników było bardzo wyraźne już $\mathrm{u}$ progu narodzin polskiej inspekcji pracy w dwudziestoleciu międzywojennym, kiedy to pod wpływem radykalizujących się nastrojów społecznych oraz przybierającego na sile ruchu robotniczego w wielu krajach ówczesnej Europy wprowadzane były przepisy przyznające inspekcji pracy zadania mające na celu ochronę pokoju społecznego, jak również sytuujące ją w roli organu stojącego na straży socjalnych praw osób pracujących. Po drugie, regulacje dotyczące inspekcji pracy rozwijały się pod wpływem swoistych przesłanek, charakterystycznych zasadniczo tylko dla polskiej inspekcji. Wśród nich należy przede wszystkim wymienić nietypowy

56 W wyniku kolejnych zmian art. 13 treść tego przepisu była sukcesywnie uzupełniana o nowe kategorie podmiotów podlegających kontroli PIP, szerzej por. D. Makowski, op. cit., s. 242-244.

57 Por. art. 17 ustawy o PIP.

58 Podobnie J. Skoczyński, Nowa ustawa o Państwowej Inspekcji Pracy, „Monitor Prawa Pracy" 2007, nr 8, s. 395; J. Zalewski, op. cit., s. 2-3; M. Gersdorf, J. Jagielski, K. Rączka, op. cit., s. $10-11$.

59 Por. art. 10 ust. 1 pkt 3 i 4 w zw. z art. 1 ustawy o PIP.

60 Por. D. Makowski, Zadania inspekcji pracy w zakresie nielegalnego zatrudnienia - wybrane problemy, [w:] Z zagadnień wspótczesnego prawa pracy. Księga jubileuszowa Profesora Henryka Lewandowskiego, red. Z. Góral, Warszawa 2009, s. 389. Podobnie J. Iwulski, W. Sanetra, Kodeks pracy. Komentarz, Warszawa 2013, s. 156. 
rodowód naszej inspekcji pracy związany z rekonstrukcją państwa polskiego po latach pozostawania pod zaborami, a także wydarzenia społeczno-polityczne, jakie miały miejsce w Polsce na początku lat osiemdziesiątych ubiegłego wieku, które legły u podstaw modelowych zmian wprowadzonych w ustawie o PIP z 1981 roku.

Nieuchronnie nasuwa się pytanie o przyszłość inspekcji pracy w Polsce, jak również o kierunki dalszego rozwoju przepisów dotyczących tej inspekcji ${ }^{61}$. Pewnych podstaw do formułowania wypowiedzi na ten temat dostarczają najnowsze zmiany przepisów dotyczących PIP, znamionujące ogólniejsze trendy legislacyjne. W sferze kompetencyjnej zauważalna jest w szczególności tendencja do stałego poszerzania zakresu zadań PIP. Tylko tytułem przykładu wymienić można włączenie do ustawy o PIP z 2007 roku zadania polegającego na sprawowaniu kontroli i nadzoru przestrzegania przepisów dotyczących legalności zatrudnienia i innej pracy zarobkowej czy też nałożenie na PIP obowiązku prowadzenia kontroli wypłacania wynagrodzenia w wysokości wynikającej z wysokości minimalnej stawki godzinowej, związanego z objęciem umów zleceń oraz o świadczenie usług zakresem oddziaływania przepisów o minimalnym wynagrodzeniu za pracę ${ }^{62}$. Innym zauważalnym obecnie kierunkiem rozwoju regulacji dotyczących zadań inspekcji pracy jest swego rodzaju ich umiędzynarodowienie w ramach tendencji do zacieśniania współpracy między inspekcjami pracy różnych państw w związku z nabierającymi coraz większego znaczenia przypadkami transgranicznego delegowania pracowników do pracy. Zadania PIP z tego zakresu reguluje ustawa z dnia 10 czerwca 2016 roku o delegowaniu pracowników w ramach świadczenia usług ${ }^{63}$, która może być jednocześnie przykładem procesu dostosowywania prawa polskiego w dziedzinie inspekcji pracy do prawa $\mathrm{UE}^{64}$. W dyskusjach nad przyszłością PIP ważne miejsce zajmować też z pewnością będzie sprawa podległości PIP Sejmowi, podnoszona już dzisiaj przez przeciwników tego rozwiązania prawnego ${ }^{65}$. Debatując nad przyszłością, warto jednak pamiętać o przeszłości, zwłaszcza w tym szczególnym roku obchodów setnej rocznicy utworzenia inspekcji pracy w Polsce. Wiedza na temat rozwoju regulacji dotyczących ustroju i kompetencji tej inspekcji ma bowiem nie tylko walor czysto poznawczy, ale może też odegrać ważną rolę w procesie dokonywania wielu trudnych wyborów legislacyjnych, przed którymi staje współczesny prawodawca.

61 Szerzej o tym por. D. Makowski, Aktualne kierunki legislacji dotyczacej Państwowej Inspekcji Pracy - wybrane problemy, [w:] Prawo ochrony pracy - współczesność i perspektywy rozwoju, red. T. Wyka, M. Mielczarek, Warszawa 2017, s. 113 n.

62 Por. art. 8a w zw. z art. 2 ustawy z 10 października 2002 roku o minimalnym wynagrodzeniu za pracę, tekst jedn. Dz.U. z 2018 r. poz. 2177.

63 Tekst jedn. Dz.U. z 2018 r. poz. 2206.

64 Por. w szczególności dyrektywę Parlamentu Europejskiego i Rady nr 2014/67/UE w sprawie egzekwowania dyrektywy 96/71, Dz. Urz. UE L 159 z dnia 28 maja 2014 r.

65 Szerzej por. D. Makowski, Inspekcja ...., s. 95-109. 


\title{
DEVELOPMENT OF REGULATIONS REGARDING THE SYSTEM AND DUTIES OF LABOUR INSPECTION IN POLAND
}

\author{
Summary
}

In 2019, one hundred years have passed since the birth of labour inspection in Poland. From a historical point of view it is also possible to distinguish three main periods of development of regulations regarding the system and duties of this inspection: the interwar period, the communist period and the period of the Third Polish Republic. Taking into account the range of the influence of the social, economic and political conditions on the Polish legislation concerning the labour inspection, they can be divided into two groups. The first includes the conditions of the universal (global) character that reflect some general trends and processes. The second group has a local range. Its determinants refer to the specific conditions which are, in principle, characteristic only of the labour inspection in our country.

Keywords: inspection, supervision, work, system, duties

\section{BIBLIOGRAFIA}

Banaszak B., Konstytucja Rzeczypospolitej Polskiej. Komentarz, Warszawa 2012.

Barański J., Orzekanie przez inspektorów pracy w sprawach o wykroczenia przeciwko prawom pracownika, Warszawa 1984.

Gersdorf M., Jagielski J., Rączka K., Komentarz do ustawy o Państwowej Inspekcji Pracy, Warszawa 2008.

Iwulski J., Sanetra W., Kodeks pracy. Komentarz, Warszawa 2013.

Kijowski A., Odpowiedzialność za wykroczenia przeciwko przepisom ustawodawstwa pracy, [w:] Studia nad kodeksem pracy, red. W. Jaśkiewicz, Poznań 1975.

Klott M., Inspekcja pracy w Polsce, Warszawa 1937.

Knyziak J., Związkowy nadzór nad warunkami pracy — w jakiej formie możliwy obecnie?, „Ochrona Pracy" 1981, nr 4.

Kołodziejczyk E., Inspekcja pracy w Polsce 1919-1999, Warszawa 2003.

Kozłowski T., Proces scalania Inspekcji Pracy w Polsce w latach 1919-1928, „Prawo” 2006, nr 298.

Krahelska H., Kirstowa M., Wolski S., Ze wspomnień inspektora pracy, t. 1, Warszawa 1936.

Landau W., Drogi rozwoju polskiego ustawodawstwa pracy, [w:] Na froncie gospodarczym. Wdziesiata rocznice odzyskania niepodległości, Warszawa 1928.

Licki J., Prawo pracy w zarysie. Część II - szczegółowa, Warszawa 1969.

Lipiński E., Inspekcja pracy, Warszawa 1916.

Liszcz T., Państwowa Inspekcja Pracy — strażnik praworządności w stosunkach pracy, „Kontrola Państwowa" 2006, nr 3.

Makowski D., Aktualne kierunki legislacji dotyczacej Państwowej Inspekcji Pracy — wybrane problemy, [w:] Prawo ochrony pracy — wspótczesność i perspektywy rozwoju, red. T. Wyka, M. Mielczarek, Warszawa 2017.

Makowski D., Inspekcja pracy jako instytucja państwowego nadzoru nad przestrzeganiem prawa pracy, Łódź, 2017.

Makowski D., Zadania inspekcji pracy w zakresie nielegalnego zatrudnienia - wybrane problemy, [w:] Z zagadnień wspótczesnego prawa pracy. Księga jubileuszowa Profesora Henryka Lewandowskiego, red. Z. Góral, Warszawa 2009. 
Masewicz W., Kasprowicz Ł., Ochrona pracy jako problem prawnospołeczny, „Studia z Zakresu Prawa Pracy i Polityki Społecznej” 2015, nr 1.

Matey M., Inspekcja pracy — model polski a tendencje światowe, Warszawa-Łódź 1988.

Mazurkiewicz A., Zagadnienie organizacji bezpieczeństwa pracy, Warszawa 1938.

Modliński E., Inspekcja pracy. Odpowiedzialność karna w stosunkach pracy, Warszawa 1979.

Piszczek J., Administracyjno-prawne zagadnienia zwiąkowej inspekcji pracy, Torun 1971.

Raczyński A., Polskie prawo pracy, Warszawa 1930.

Rusinek K., Z dziejów walk o ochronę pracy, Warszawa 1957.

Skoczyński J., Nowa ustawa o Państwowej Inspekcji Pracy, „Monitor Prawa Pracy” 2007, nr 8.

Skrzydło W., Konstytucja Rzeczypospolitej Polskiej. Komentarz, Warszawa 2013.

Sobczyk A., Prawo pracy w świetle Konstytucji RP, t. 1, Warszawa 2013.

Sobczyk A., Buch D., [w:] Konstytucja RP, t, 1, red. M. Safjan, L. Bosek, Warszawa 2016.

Szczerski J., Państwowa Inspekcja Pracy, „Praca i Zabezpieczenie Społeczne” 1981, nr 9.

Szubert W., Zarys prawa pracy, Warszawa 1980.

Święcicki M., Instytucje polskiego prawa pracy w latach 1918-1939, Warszawa 1960.

Ustawa o pracy w przemyśle, red. S. Szymorowski, Warszawa 1922.

Wąsowski J., Techniczna inspekcja pracy, Warszawa 1959.

Winczorek P., Komentarz do Konstytucji Rzeczypospolitej Polskiej z dnia 2 kwietnia 1997 roku, Warszawa 2008.

Zalewski J., Państwowa Inspekcja Pracy — organizacja, zakres działania i uprawnienia, „Inspektor Pracy", dodatek tematyczny 2007, nr 2.

\section{AKTY PRAWNE}

Dekret Naczelnika Państwa z dnia 3 stycznia 1919 roku o urządzeniu i działalności inspekcji pracy, Dziennik Praw Państwa Polskiego nr 5, poz. 90.

Dekret Rady Państwa z dnia 10 listopada 1954 roku o przejęciu przez związki zawodowe zadań w dziedzinie wykonywania ustaw o ochronie, bezpieczeństwie i higienie pracy oraz sprawowania inspekcji pracy, tekst jedn. Dz.U. z 1968 r. Nr 8, poz. 47 ze zm.

Dyrektywa Parlamentu Europejskiego i Rady nr 2014/67/UE z dnia 15 maja 2014 r. w sprawie egzekwowania dyrektywy 96/71/WE dotyczącej delegowania pracowników w ramach świadczenia usług, zmieniająca rozporządzenie (UE) nr 1024/2012 w sprawie współpracy administracyjnej za pośrednictwem systemu wymiany informacji na rynku wewnętrznym („rozporządzenie w sprawie IMI"), Dz. Urz. UE L 159 z dnia 28.05.2014 r.

Konstytucja Polskiej Rzeczypospolitej Ludowej z dnia 22 lipca 1952 roku, tekst jedn. Dz.U. z 1976 r. $\mathrm{Nr} 7$, poz. 36 ze zm.

Konstytucja Rzeczypospolitej Polskiej z dnia 2 kwietnia 1997 roku, Dz.U. Nr 78, poz. 483 ze zm. Konwencja MOP nr 81 z dnia 11 lipca 1947 roku o inspekcji pracy w przemyśle i handlu, Dz.U. z 1997 r. Nr 72, poz. 450.

Rozporządzenie (z mocą ustawy) Prezydenta Rzeczypospolitej z dnia 14 lipca 1927 roku o inspekcji pracy, Dz.U. Nr 67, poz. 590 ze zm.

Zalecenie MOP nr 20 z dnia 29 października 1923 roku o inspekcji pracy.

Ustawa konstytucyjna z dnia 23 kwietnia 1935 roku, Dz.U. Nr 30, poz. 227.

Ustawa z dnia 4 lutego 1950 roku o społecznej inspekcji pracy, Dz.U. z 1955 r. Nr 20, poz. 134.

Ustawa z dnia 20 marca 1950 roku o terenowych organach jednolitej władzy państwowej, Dz.U.

$\mathrm{Nr} 14$, poz. 130 ze zm.

Ustawa z dnia 30 marca 1965 roku o bezpieczeństwie i higienie pracy, Dz.U. Nr 13, poz. 91 ze zm. Ustawa z dnia 26 czerwca 1974 roku Kodeks pracy, tekst jedn. Dz.U. z 2019 r. poz. 1040 ze zm.

Ustawa z dnia 6 marca 1981 roku o Państwowej Inspekcji Pracy, tekst jedn. Dz.U. z 2001 r. Nr 124, poz. 1362 ze zm. 
Ustawa z dnia 24 lipca 1985 roku o zmianie ustawy o związkach zawodowych i niektórych innych ustaw określających uprawnienia związków zawodowych, Dz.U. Nr 35, poz. 162.

Ustawa z dnia 29 maja 1989 roku o przekazaniu dotychczasowych kompetencji Rady Państwa Prezydentowi Polskiej Rzeczypospolitej Ludowej i innym organom państwowym, Dz.U. Nr 34, poz. 178 .

Ustawa z dnia 2 lutego 1996 roku o zmianie ustawy — Kodeks pracy oraz o zmianie niektórych ustaw, Dz.U. Nr 24, poz. 110.

Ustawa z dnia 10 października 2002 roku o minimalnym wynagrodzeniu za pracę, tekst jedn. Dz.U. z 2018 r. poz. 2177.

Ustawa z dnia 13 kwietnia 2007 roku o Państwowej Inspekcji Pracy, tekst jedn. Dz.U. z 2019 r. poz. 1251.

Ustawa z dnia 10 czerwca 2016 roku o delegowaniu pracowników w ramach świadczenia usług, tekst jedn. Dz.U. z 2018 r. poz. 2206. 